\title{
TET2 Negative
}

National Cancer Institute

\section{Source}

National Cancer Institute. TET2 Negative. NCI Thesaurus. Code C157113.

An indication that TET 2 expression or activity has not been detected in a sample. 